\title{
Children's Grief and Creativity: The Experience of Losing a Sibling
}

\author{
Marcela Lança de Andrade - Universidade de São Paulo Ribeirão Preto, Brasil \\ Fernanda Kimie Tavares Mishima-Gomes - Universidade de São Paulo, Ribeirão Preto, Brasil \\ Valéria Barbieri - Universidade de São Paulo, Ribeirão Preto, Brasil
}

\begin{abstract}
When children lose one of their siblings, they seek their parents' emotional support. However, because their parents also feel the loss of one of their children, they cannot provide adequate emotional support for the living ones. Consequently, children have difficulty mourning that loss. This study aims to understand the psychodynamics of children who lost a sibling. The research involved three children, two boys at the age of 11 and 12, and a girl at the age of eight. Individual sessions were conducted to apply the House-Tree-Person Test (HTP) and the Fables Test with the children. Family environments were fragile, driving participants to suppress their feelings and develop symptoms such as learning disability, fear of death, psychosomatic symptoms, dependency, and difficulty in the symbolization process. To express their grief, children need to use their creativity, with the aid of an external environment that offers holding. Such setting allows them to express anguish and anxiety, and to resume their emotional development, despite the difficulties.
\end{abstract}

Keywords: mourning; siblings; creativity.

\section{Luto infantil e Capacidade Criativa: A Experiência de Perder um Irmão}

\begin{abstract}
Resumo
Quando as crianças perdem um irmão buscam o apoio emocional dos pais, contudo, estes, por também viverem essa experiência de perda, têm dificuldade para oferecer suporte afetivo aos filhos, o que dificulta a elaboração do luto da criança. Esse estudo objetivou compreender os psicodinamismos de crianças que perderam um irmão. Participaram três crianças, dois meninos de 11 e 12 anos e uma menina com 8 anos. Foi realizado um encontro com cada criança em que se aplicou o Teste da Casa-Árvore-Pessoa (HTP) e o Teste das Fábulas. O ambiente familiar se apresentou como frágil aos participantes, o que os faz reprimir seus sentimentos, ocasionando o surgimento de sintomas, como medo da morte, sintomas psicossomáticos, dependência dos pais, dificuldades de aprendizagem e do processo de simbolização. Para elaborar o luto, as crianças precisam utilizar da sua capacidade criativa, com auxílio de um ambiente externo disponível, que permita a expressão das angústias e receios, possibilitando a retomada do desenvolvimento emocional apesar das dificuldades enfrentadas.
\end{abstract}

Palavras-chave: luto, irmãos, criatividade

\section{Duelo Infantil y Creatividad: La Experiencia de Perder un Hermano}

\begin{abstract}
Resumen
Cuando un niño pierde un hermano, busca el apoyo emocional de los padres, pero, estos, por también vivir la pérdida, tienen dificultad para ofrecer el apoyo afectivo a sus hijos, lo que dificulta la elaboración del luto del niño. Este estudio tuvo como objetivo comprender la psicodinámica de los niños que han perdido a un hermano. Participaran tres hijos, dos chicos de 11 y 12 años y una niña de 8 años. Se realizó una reunión con cada niño en la que se aplicaron la Test Casa-Árbol-Persona (HTP) y la Test de las Fábulas. En razón del frágil entorno familiar, los participantes reprimen sus sentimientos, y como en consecuencia, pueden tener síntomas como dificultad de aprendizaje, miedo a la muerte, síntomas psicosomáticos, la dependencia de los padres y las dificultades en el proceso de simbolización. Para elaborar el luto, los niños necesitan utilizar su capacidad creativa con la ayuda de un entorno externo accesible que permite la expresión de sus ansiedades y miedos, posibilitando la reanudación del desarrollo emocional a pesar de las dificultades que se presentan.
\end{abstract}

Palabras clave: luto, hermanos, creatividad

The process of mourning is particularly complex in children. The reactions are diverse and, sometimes, they appear to have no direct relation to the loss, arising as special forms of expression of child's feelings. Psychosomatic symptoms, difficulties in school, behavior problems, eating problems, low self-esteem, anxiety, aggression, difficulties socializing, and regressed behavior are some examples of these reactions (Howarth, 2011; Lima \& Kovács, 2011). The experience of loss can also affect child's perception of themselves and the external environment, causing them to develop a feeling of non-belonging (Graham, 2004; Green \& Connolly, 2009).

To understand death, the child must acquire its concept. Through the cognitive development, the child introjects some characteristics that are inherent to death, such as irreversibility, non-functionality, and universality, thus enabling understanding (Torres, 1999). However, the way a child experiences grief is also affected by what they learn about the loss, and by 
opportunities they are given to share their thoughts and feelings. In this sense, the way the family copes with mourning is crucial in determining how the child will do, since communication and acceptance from those close to them can reduce the impact of the loss in child's life (Kovács, 1992).

Because they are very observant and can easily perceive what is happening around them, children often become spokesperson for the anxieties that adults manifest (Aberastury, 1984). Therefore, it is necessary for the child to understand what happened, so their mourning is processed in the best possible way (Lima \& Kovács, 2011). Difficulties in this process of understanding begin when, after the death of a loved one, the bereaved family, suffering from the grief-derived feelings, may not be able to offer the shelter and attention that the surviving child needs.

During mourning, the child must be allowed to feel sad. Unfortunately, there may be those who try to force them into a state of false joy, forgetting that the natural tendency is for them to recover from the loss, if their rhythm and momentum are respected (Winnicott, 1959/1997). Caregivers need to reassure children. They have to respect those fantasies out of tune with reality that may arise and, gradually, work with the child until they can distinguish between fantasy and reality. Children often develop a fantasy in which they have done something wrong and must be blamed for the death of their loved one. Lima and Kovács (2011) affirm that in perceiving the withdrawal and suffering of their relatives, the child tends to offer shelter to them, hiding their own grief. This role reversal is harmful, particularly to the child, but to all the mourners as well.

Thus, children should be encouraged to talk about their feelings. However, many adults believe that children are unable to understand the truth, and they are afraid of harming them by talking about death (Mazorra, 2009). These are negative attitudes that hamper the process of child's mourning (Librach \& O'Brien, 2011). Including the child in conversations about loss enables them to feel less lonely in their sorrow, producing a shared grief that will help them grow and mature (Kübler-Ross, 1981/2005). When death is communicated freely and the child is given space to openly talk about their feelings, they find it easier to express them and mourn.

In addition to the difficulties inherent to the loss of a loved one, a sibling's death can arouse different types of anxiety in children. In sibling relationships, there are many ambivalent feelings, many of which are anxiogenic, permeated by competitiveness, love, and jealousy. Fraternal rivalry is a natural process and can exist for a variety of reasons, from dispute and competition in games to the desire to receive more attention from parents (Pereira, 2011). In this relationship, aggressiveness can exist through fraternal conflicts, and by experiencing these moments, the bonds between siblings may even strengthen, as well as the development of satisfying relationships in adult life. Hence, fraternal relationship is very important in the constitution of the subject, because siblings define their identity from the perception of similarities and differences between them (Goldsmid \& Féres-Carneiro, 2011).

In the event of a sibling's death, the bereaved siblings can also - and this seems to be a psychic rule feel guilty for surviving and for the deceased sibling no longer being able to experience the same situations as them. Surviving siblings can introject and take over the expectations that parents had about their deceased children and, at the same time, stagnate in their emotional development (Zimerman, 1993; Lima \& Kovács, 2011). This stagnation results in creativity paralysis, that is, the individual ceases to be someone and "dies" just like the lost object.

Thus, these children are prone to develop some kind of symptom, which is a manifestation of the psychic damage they have suffered. Moreover, not being able to elaborate mourning in childhood can be very bad for adulthood, since the individual may give up trying to elaborate their emotions and may feel persecuted by a sadness they cannot explain well (Pincus, 1989).

Besides losing a sibling, children suffer another loss, as their parents may not be available to them due to their own sufferings, caused by the loss (Gerhardt et al, 2012). Mourning parents may become depressed and distant from their other children, which is very traumatizing for them. Unable to understand parental suffering, children may feel a loss of meaning regarding their presence in their parents' lives, as a result of not having the love and attention that hitherto had been devoted to them (Green, 1988). According to Winnicott (1960/2008), maternal depression can be very harmful to the child, because, being mothers unable to meet children's needs, the development of the potential of their self might be hampered, that is, their creativity. Ireland (2011) conducted a case study on a patient who, after losing his siblings, had his mother depressed. That situation made him experience "a grief 'wrapped' in another grief" (p. 159) because, in addition to losing a 
brother, he also lost their mother, who could no longer be devoted to her living child as before.

Following the loss, the work of mourning is possible through the creative capacity of the bereaved, which enables their inner world to be repaired, so that they can feel again that life is worth living (Barone, 2004). Creativity is the basis of healthy living (Winnicott, 1971/1975) and play is an expression of creative living, in which it is possible for the child to elicit reality and to elaborate it (Barone, 2004). In this sense, the elaboration of the feelings of mourning can happen through the individual's creative expressions, which arise in the search for a resignification of life after the loss.

According to Winnicott (Abram, 1996/2000) creativity appears as an innate impulse, which can be developed according to experiences. The initial experience is the process of illusion, that is, the baby's omnipotence that is nourished by the mother's ability to respond to the spontaneous infantile gesture. This experience is creativity's first appearance. Subsequently, the baby will feel safe to tolerate frustrations and experience reality, being able to make use of their personal style of being.

Thus, the environment must provide security and bolding to facilitate the child's expression and allow them to be spontaneous and resume their creative capacity (already lived in the process of illusion), following with their emotional maturity despite the environmental failures. The use of creativity is recognized through "being alive" and feeling real, contributing to the resignification of the experience of loss and the elaboration of feelings aroused in this situation, without deeply compromising the continuation of being and spontaneous living (Winnicott, 1971/1975). In other words, the individual who loses a loved one is able to continue to be and feel real, despite the experienced loss, by making use of their creative capacity.

This study aimed to understand the psychodynamics of children who lost a sibling, their creative expression in the world and their experience of loss, main anguishes and defenses. Hence, we intend to reflect on the experience of mourning in the child and in their family environment, and on the possible repercussions on the emotional development of children.

\section{Method}

This work is part of the Master's Dissertation "After the storm: a psychodynamic study of children in mourning and their parents", aimed to understand the experience of three children, from different families, who lost a sibling each, and the repercussions on their emotional development from the experience of mourning. This qualitative research was based on a case study, developed from the application of projective tests, and data analysis according to Winnicott's psychoanalytic approach.

\section{Participants}

An 11-year-old boy, a 12-year-old boy, and an 8 -year-old girl participated in this study. Their respective families were identified while seeking psychological care for their children, and the professionals responsible for their care were the first to communicate about the possibility of participating in the research. The children's mothers were interviewed; however, data from these interviews will be used in this study only to contextualize the life history of these children and their families.

\section{Instruments}

Two instruments were used to communicate with the child: the House-Tree-Person Test (HTP), and the Fables Test. Regarding the first one, the child was requested to draw three objects (house, tree, and person), and then answer questions about the produced drawings. In the fables test, the child was presented with 10 incomplete fables and they were told to complete the stories as they wished. The instruments' main objective was to provide information about children's psychodynamic functioning, regarding self-image, egoic capacity, use of defenses, expression of the self, creativity, etc. A semi-structured interview was conducted with the mothers, having as guiding questions "Tell me about your family" and "Tell me a typical day in your family", which enabled to address the story of their children's death and developmental aspects of the children enrolled in the study. The information provided by the interviews had little significance to the analysis, but it enabled us to understand the family context in which the participating children are inserted.

\section{Procedures}

Following the health professionals' first contact with the families, the researcher arranged a meeting with each family to explain the work and request to sign the Free and Informed Consent Term, in case they were willing to participate. The next stage, after receiving their parents' consent, consisted of a meeting held with each child, in which the House-Tree-Person 
Test (HTP) and the Fables Test were applied. Individual interviews were conducted with each mother, using guiding questions to collect the stories of the siblings' deaths and other issues about the development of the participating children.

The data obtained in the meetings was analyzed according to the method of free inspection of the clinical-qualitative material (Trinca, 1984), with emphasis on Winnicott's psychoanalytical theoretical framework, plus information obtained from the manuals of HTP and Fables Test instruments (Buck, 1964/2003 and Cunha \& Nunes, 1993). All ethical aspects have been contemplated. Names cited in this paper are fictitious for preserving participants' identity.

\section{Results}

\section{Case 1 - Rodrigo}

Rodrigo's family sought psychological care for the 11-year-old boy, upon advice from his school, due to his learning difficulties and hyperactivity. When psychological screening revealed that the mother had lost two children, they were invited to participate in the study.

Rodrigo had two siblings who died and whom he has never met. The first was a girl who was born premature (24 weeks), remained hospitalized at birth for 2 weeks, and died from an infection. The second brother died after contracting meningitis at 6 months of age. In addition to the deceased siblings, Rodrigo has two sisters, a 22 -year-old, and a 14-year-old who was adopted by his parents.

Rodrigo was born into his mother's second marriage; his father is chemically dependent and, at the time of the research, was hospitalized in a specialized clinic. His mother carries the HIV virus, treats the disease, but keeps it from her children, simply saying that she needs to take some medicine to stay healthy. Rodrigo's mother also had two miscarriages in her second marriage. Rodrigo was born after all those losses and following the 6-month-old baby's decease. Upon his birth, his mother decided he would be her last child.

During the HTP test application, Rodrigo's behavior was very shy. He finished the drawings only after repeatedly emphasizing his inability to draw ("I can't draw", "I can't do it"), having spoken very little during the assessment. It was noticeable, from the produced drawings, that Rodrigo seems to be a dependent child (tree drawn with broad trunk), who feels the need to achieve independence but finds many difficulties in this process (fragile legs in the person drawing). The external environment can be seen as hostile and insecure, making him feel the need to protect himself and having difficulty in relating to others (small roof, an absence of windows, and door displaced from the house). Thus, he seems to have a feeling of inadequacy (he answers in the assessment: "the house is more or less mine") that prevents him from acting in the environment spontaneously and creatively, especially because he feels that his needs will not be met (tree branches that were drawn cut; difficulty in making the drawings and answering the questions).

The family setting seems very fragile and unlikely to meet Rodrigo's needs (in the assessment, the boy drawn cannot fulfill his desire). This forces him to contain his needs and not to express his feelings, especially those of aggressive content (the drawing of the house has been reinforced several times), which causes him a great impression of futility, a characteristic feeling of a false-self functioning (Winnicott, 1960/2008). Consequently, there seems to be a blockage in the expression of fantasy (lack of neck in the person drawing, no delimitation between tree top and trunk, branches cut, and frequent answers "I don't know" in the surveys of the drawings), with demonstrations of low self-esteem and difficulty in expressing himself ("I don't know how to draw people", "I didn't do it right"). Without having his needs met, and in the face of his inability to express himself creatively in the world, the learning process becomes more difficult and, thus, school difficulties appear. However, Rodrigo demonstrates hope that he can be taken care of and receive what he needs (in the assessment he says "the house needs to be painted", "the tree is watered every day").

In the Fables test, Rodrigo demonstrated difficulty in acting spontaneously in the world, with distrust of his own resources (in his version of fable 1 the little bird does not know if he will find its parents). There is also evidence that he perceives himself as very dependent, especially on the mother figure, with great fear of feeling and experiencing new losses in life (in fable 4 he stated that he did not know who had died and refused to continue the story). Afraid of suffering losses, he shows himself as a submissive child, worrying about meeting expectations about him so as not to displease (in fable 3 the character recognizes the birth of the brother and offers him his food). It was perceivable that Rodrigo seeks to adapt to living without being paralyzed by fear and anguish of experiencing difficult moments, and tries not to let these feelings provoke some kind of loss, especially felt due to the fragility of 
his parents. This makes him insecure and makes him repress his feelings, especially aggressive ones, so that no situation further destabilizes the family environment (in fable 2 the child says he does not know why the character left, feeling extremely distressed, unable to develop the story - "I don't know, I don't know").

Rodrigo shows a lot of admiration for his 14-year-old sister, because, unlike him, she is able to express herself spontaneously in the environment. This admiration causes him to realize that it is important to be truthful and spontaneous but, at the same time, distresses him, since he seems to feel unable to act in this way, fearing his feelings might destabilize his mother (in fable 6 the little elephant must leave his house because he grew up, making his mother very sad).

Rodrigo also seemed to demonstrate the belief that a child should do what is expected to do, that is, to meet maternal expectations and cancel their feelings in pursuit of the family stability and union (in fable 7 , the boy gives the object that he likes to his mother "just because "she asked). It is possible to think that Rodrigo's emotional development seems limited to the condition of the environment, which does not offer him support and understanding of his own feelings, but makes constant demands instead.

\section{Case 2 - Leonardo}

Leonardo's mother sought psychological care for her 12-year-old son under complaints of his learning difficulties and stating he did not want to attend school. Among other symptoms, he also had undiagnosed fainting episodes. His psychologist, after identifying the death of other children in the family, referred him to the research.

Leonardo had lost three siblings. The first one, he did not get to meet, was born premature and died of a cardiac arrest soon after delivery. The second, who was his twin, died inside his mother's womb (two days before delivery), which complicated Leonardo's birth (according to his mother, he had to push the dead brother to be born). The third, a 14-year-old girl, died of cancer when Leonardo was 5 years old. This was a difficult time for the family, and it still mobilizes them intensely: many rituals are held to keep the memory of the deceased daughter, such as maintenance and care of some objects and frequent visits to the cemetery. In addition to these deceased siblings, Leonardo has three more brothers: of 15, 17 and 20 years old.

It was perceivable, from the application of the HTP test, that Leonardo feels insecure and that his needs cannot be satisfied, with evidence of having experienced insufficient holding (house roof drawn in pieces; house is crooked and sloping; lack of ground line in the drawings; in the assessment, he answers that the tree needs "everything for its survival"). Hence, he seems to seek immediate gratification in a voracious and impulsive way, without, however, finding the necessary limits to delineate his attitudes in the external environment, which causes great anxiety (tree drawn in single contour, with no delimitation of treetop and trunk; absence of details in the drawings; using left side of the sheet). Besides the lack of limits, it is possible to think of the damage in integrating reality and fantasy, intensifying his impulsive behaviors, and making it difficult for Leonardo to live satisfactorily in the shared reality, with difficulties in perceiving himself in the family setting (in the house assessment he states that only the mother and the stepfather live in it).

In addition, the family is valued when all the siblings are present in the drawing, even the deceased, especially the girl who died at age 14 (the human figure drawn reminds the sister, whose main need is to eat because she is lean). It is also possible to think that the family conflicts may not exist because they threaten the union, already shaken by the difficulties created by so many losses (in the assessment he says that the tree "will only live if no one cuts it, but it has been cut before", and this same tree reminds the 15-year-old brother). Some signs point to a regressed behavior in Leonardo, in addition to low self-esteem and difficulties in acquiring autonomy (poor drawings with no details, human figure simply drawn), making it difficult for him to trust his own resources to find what he needs and interact effectively with external reality.

The Fables Test shows that Leonardo's aggression and experience of fraternal rivalry are problematized by the lack of limits and continence (in fable 2 the character eats too much and feels sick, needing medical attention). Such voracious attitudes make him feel that he can have everything for himself, especially from the mother, withdrawing from the brothers what she could offer them, strengthening the guilt and feelings of fraternal rivalry (for he believes he can effectively destroy objects like his brothers). In fable 8 the character kills his father's fish out of frustration (the father did not want to give him a dog); this intolerance to frustration also appears in the next fable, in which the father dies and, in order not to be sad, the mother buys a gift for her son. That story also enables us to think that the mother has difficulties offering 
enough holding to support their children in bearing painful feelings and the relationship with the external environment, considered as hostile (In fable 6, the elephant takes poison and dies, the child becomes sad and the mother gives him another elephant, so that they do not suffer this loss).

Leonardo demonstrates a great deal of identification with his siblings, acts to keep their memories alive, as a way of repairing the fraternal rivalry (after telling the story of fable 3 , Leonardo stated that he kept the toys that belonged to his deceased sister, not allowing the mother to dispose of them. He also told that visits to the cemetery were frequent, to take care of the tomb). In this sense, Leonardo also wants to ensure that his mother does not forget the deceased children in their psychic reality, because he is afraid that if she forgets his siblings, she can forget him too. Hence, it is as if he feels responsible for keeping their memories, keeping rituals such as storing objects and going to the cemetery, taking up his mother's grief in her place, and constantly showing his siblings' absence to make them present, without, however, being able to elaborate the feelings derived from these difficult experiences.

With so many poorly elaborated issues related to the death of his siblings and the fear of losing the maternal figure's care, Leonardo seems to act in a regressed and self-directed way (his mother's initial complaint was that he had constant fainting and could not be alone in school, which made him no longer attend it). Aggression and voracity are seen as his main form of expression. Through them, he demonstrates the need to receive limits that circumvent his existence and offer him security to act spontaneously in the world (In fable 2, the child leaves the party because they are ill from having eaten too much, receives medicine, improves and does not return to eating much. In fable 10 , the character has nightmares in which the "bogeyman" is going to eat them; as a solution, they suddenly stop dreaming and "all is well"). As much as Leonardo requires the environment to set him limits, it does not happen, mainly because the maternal figure is not in a condition to offer what he needs. Thus, it becomes difficult to reconcile the internal and external realities, especially by the lack of security felt in the environment and in him. The loss in the self-other differentiation stands out and, added to the fear of destroying the object because of his voracious and impulsive attitudes, compromises the development of his symbolic capacity, allowing him to feel that he can only exist in worshipping his dead siblings.
Case 3- Isabela

At the age of eight, Isabela was taken by her mother to psychological care, with complaints of tachycardia, nausea, fear of being alone, difficulty sleeping, hearing voices in her head, and recurring thoughts about death. Isabela is the daughter of her mother's second marriage. From her mother's first marriage she has a 22-year-old sister and a brother who died suddenly at the age of 14 , who became ill with flu-like symptoms and died within a week. Isabela did not know her brother, because she was born a year after his death, but she knows his story: she was told that he fell ill because he disobeyed their mother, walked barefoot and "caught chill". Her mother's difficulty in dealing with her own mourning and Isabela's is noticeable; death as a consequence of disobedience is an attempt to self-exonerate, placing the blame on the dead child. Isabela's father, who is also in his second marriage, has other children and constantly needs to help them with several problems. In order to lessen Isabela's symptoms, her parents have resorted to all kinds of help, based on beliefs and religions, but as the situation worsened, they decided to seek psychological help.

In her HTP drawings, Isabela showed insecurity towards the environment, as if it could not meet her needs, and did not provide her with enough holding (in the house assessment she replied that it was her house, but it also looked like an abandoned house, "full of bugs and dangers that can hurt". About the tree, she said that it recalled her of a neighbor who told only bad news and frightened her with dangerous situations).

In seeking to have her needs met, Isabela realizes the mother figure does not help her, so she seeks the paternal figure, which also proves to be insufficient (in the house inquiry she said she would like to put stickers on the bedroom wall, but she cannot, her mother does not allow it. She also says that the house is full of dangers, and even the masons were careless and left nails on the floor that hurt her foot). In an environment that does not provide what she needs, Isabela feels "disabled", with little capacity to mature and achieve the autonomy she needs to trust herself and deal with her anguish (in the assessment about the human figure, she identifies herself with the girl drawn and adds that she may also be a school friend who, due to a disability, cannot make many friends). In addition, Isabela is also terrified of losing her parents, for she sees that without them she would be abandoned, without the basics for survival and could die (in the tree assessment, she said that the tree had died because "it lacked water". 
Of the human figure, she said that people who do not have a father or mother are "depressed"). Despite the feeling of lack of protection, Isabela struggles to act in the environment and seeks to understand her own difficulties. She finds a little of what she needs in pair relationship, where there is a possibility of existing in a creative and spontaneous way (when doing the house assessment, she completed the drawing by making one more window and said it was for the guest room. Of the human figure, she stated that it was happy, in a garden, "saying hello").

Feelings that prevent her from taking action, like insecurity and fear of being abandoned, surfaced again during the Fables Test (in her version of fable 1 the bird could not fly because it had to wait for its mother return, but the mother could be hiding from it or even never return). Such insecurity increases as she realizes that growing up means distancing herself from her parents, so she increasingly demonstrates the need for their presence, even though they do not effectively help her lessen her fears (in fable 2, the character leaves the party because their mother is no longer offering affection and attention, she only wants to take care of her husband - "she thinks: will I have neither love nor affection from my mother? Only from my father?"). Isabela shows little confidence in family's care and protection and has the feeling that she is unwanted (in fable 6 the elephant left the house because the door was left open). For this reason, she requires their attention to herself in order to deconstruct this impression. However, the mother is still very depressed by the loss of her child and the father remains involved in his eldest children's several problems, leaving little care and space for Isabela in her parents' life (in Isabela's rendering of fable 3 , the younger lamb is sad because the older will not stop drinking the milk).

Isabela's symptoms make her parents revive their issues about death and loss of their objects of affection, representing their fears and anxieties by making that reality undeniable. However, even with the onset of symptoms and Isabella's need to talk about losing her brother, her parents cannot help her work out the feelings, something they have not been able to do with their own feelings yet. It seems as, through somatization, Isabela could find a link between her family and reality, between the family's feelings of loss and their resumption of grief. Isabela expresses herself through her symptoms, hoping that this will bring the help, shelter, and explanations she needs in order to understand death and other issues that torment her, so she can finally feel safe and whole. She takes upon herself the need to mourn and work on the feelings of loss so that life can be lived fully, though she is still unsure about the possibility of her family's survival.

\section{Discussion}

The way children express their creativity is greatly influenced by the external environment, as it enables them to express their true self, feeling that they have a place in the world and that they can be themselves. The three participants demonstrated living in an insufficient environment, with little affection and attention to their needs, which seems to have contributed to a loss in spontaneous expression and the capacity for symbolization. It is perceivable, however, that these children demonstrate the desire to relate to the environment, hoping that it can fulfill their needs, especially in accepting the anguish generated after losing their siblings.

The children perceived the family environment as very fragile, unprotected and taken by anguish, especially due to the difficulty in dealing with the loss of the child, which consequently generated difficulties in receiving and enabling the living child to elaborate mourning. Such insecurity felt in the family environment also makes children afraid of expressing their negative aspects, for they doubt their parents could survive it. Aggressiveness is important in expressing the true self and it is not always negative (Winnicott, 1939/2012). Rodrigo and Isabela perceive aggressiveness as a disturbance to the family's union, so they feel the need to restrain it. Whereas Leonardo is even able to express himself through it, however, he does so in a regressed and decontextualized way, not receiving clues from the environment to help him discriminate what is aggressive from what is not. This expression ends up generating anguish, in the form of impulsivity and voracity, demanding more and more from the environment. Restraining aggression for fear of losing the affection of parents impairs integration and, consequently, creativity capacity, because, by being able to express their aggressiveness, the child realizes that they did not damage the object of affection, and they are, therefore, able to feel real.

In this context, manifestations of fraternal rivalry are discouraged. Disagreements between siblings cannot happen because they could further intensify conflicts and break up the family. These children's growth is stagnated as a result of the guilt of being alive and able to grow up, while their deceased siblings cannot 
(Zimerman, 1993; Lima \& Kovács, 2011). Leonardo was very close to his sister and her loss was deeply felt by him and his other siblings. Isabela identifies with her deceased brother to the point of fearing her own death (even more so for being close to the age her brother was when he died), an unusual concern for a child. Rodrigo believes that he must submit to the environment to soften the feelings aroused from the death of his siblings and not to collaborate even more with the fragility and destabilization of the family.

Isabela wants to understand her feelings but feels like she is alone. Therefore, her fantasies become too frightening and one of the ways she deals with reality is through rationalization, as she did when presenting rational excuses and explanations for her drawings and fables versions. Because she feels lonely, Isabela believes she must only count on herself, however, understanding the reality she is inserted is difficult without the participation of her parents, who cannot help her because they also have difficulties in experiencing creativity. Therefore, we understand that she, unlike her parents, is able to demonstrate her anguish towards the loss, but does not receive understanding and safety from the family group, who is unable to express themselves freely through spontaneous actions.

Through her symptoms, Isabela reminds the family of the experience of loss, providing an opportunity to receive and elaborate these feelings, which would contribute to resuming the emotional development of the entire family. She makes her fears public and expresses herself in every way she can, as a way of opening the family's difficulty in mourning. Sometimes siblings represent the possibility of mourning without the parents feeling directly responsible for the attachment or detachment of their deceased children. In difficult situations, it is common for the child to serve as the family's spokesperson since they are able to observe and manifest what is in the family environment, which is unconsciously inserted in themselves (Aberastury, 1984).

Leonardo presented the most impaired emotional development. Finding it difficult to discriminate fantasy and reality, he acts in the world impulsively and uncoordinatedly, ignoring reality (going to school loses meaning, so he stops going). The difficult conditions of Leonardo's birth enable us to think that, in order to be born, he had to materialize the death of his brother, as if he had to remove everything from the other to receive something from the maternal figure. In worshiping the image of the deceased sister, he makes her alive within the family, for if everyone is alive he will feel so as well. Thus, in order to receive constant attention from his mother, he shows himself as infantile and extremely dependent. According to Lima and Kovács (2011), regressed behaviors in bereaved children are common, as well as social and academic losses, besides maintaining a fanciful relationship with the deceased through the unhealthy internalization of non-shared pain. Moreover, in view of the difficulties these children face in the process of symbolization, feelings can be manifested by the body (Bromberg, 1994), through psychosomatic symptoms, as is the case of Leonardo and Isabela.

Likewise, Rodrigo demonstrated difficulties in his capacity for symbolization. The child isolates himself and seeks to rationalize his conflicts and anxieties by submitting to the environment to protect his true self. The use of false-self becomes a defense, but it hampers creative expression even more, because, that way, he cannot show truly himself, but just a version of himself that can be accepted by the environment. He does so in order to please the other and avoid losing them, even if it means withdrawing from the spontaneous gesture.

Because there is no prospect of receiving what he needs from the other, even if he wants to develop, Rodrigo is not interested in learning tasks, even though the school environment may offer him more hope. In addition to the familial feelings related to the death of the children, Rodrigo still has to deal with the chemically dependent father. With regard to that, Figlie, Fontes, Moraes and Payá (2004) argue that children who grow up in chemically dependent families are at greater risk of having their emotional development impaired. Rodrigo demonstrates feelings of uselessness and stagnation in the family environment, fearing new losses and not existing in a true way. Winnicott (1960/2008) regards submission as a way of protecting oneself from the environment, which causes the child to isolate and grow inserted in desperate relationships, with a sense of uselessness.

Dealing with their parents' sadness, their own feelings, family changes, anguish and fear after a sibling's death is challenging. Hence, communication between parents and children is essential, for knowledge about death is very important in the elaboration of grief (Bowlby, 1973/1998, Aberastury, 1982), and this knowledge comes mainly from parental figures. When there is no honest communication with the child about death, compatible with their age, mourning becomes complicated. The concepts of irreversibility, 
non-functionality, and universality of death, mentioned by Torres (1999), are well understood by the children participating in this study. However, Isabela and Leonardo still challenge, even though through somatization, some of these concepts. Isabela suffers from the possibility of her own death, for her brother died early (close to her age) and Leonardo attributes the possibility of life through the memories and care of his deceased sister (if she disappears, he dies too).

The children's symptoms awaken in their families the memories and feelings derived from loss. As difficult as it can be, it is important for parents to talk to their children; Heath and Cole (2011) argue that if parents can see that their children's behavior may be related to mourning reactions, a greater possibility of collaboration is visualized.

The adults' silence hampers the child's understanding of what is death and how they should deal with the anguish and fear that derive from losing someone (Winnicott, 1958/2012). Parents' communication with the child should be done according to their cognitive age, but must always be sincere, because if and information is perceived as false, when questioned, the child's trust in the family will diminish (Kübler-Ross, 1981/2005). In Isabela's case, the information that her brother died because he disobeyed their mother made her very distressed, believing that her bad behaviors could also lead her to death and that she would be responsible for it. Leonardo received true information about the death of his siblings, but it was not properly addressed, considering his age. The details went beyond his understanding capacity, causing him much distress. Rodrigo, on the other hand, received superficial, scarce information, allowing him to fantasize about the event. Even though his mother wanted to protect him from dealing with difficult situations, not talking about loss in an environment where the subject is always present leaves him insecure and afraid of what may happen in his life.

The difficulties related to the death of a loved one are not only related to the damage in the communication but also by the fact that other losses happen within the death. Thus, mourning for the child/sibling also represents secondary losses: loss of routines, expectations, plans, and family roles (Green, 1988). Besides losing their sibling, the child also loses their parents who, for some time, will not be able to devote themselves to the surviving children, as they need to live their sorrow intensely. Bereaved parents may fail to provide their children with what they need, so the child feels as if they lost their place in the family because they can neither help their parents nor keep the love and care they received from them (Barone, 2004; Ireland, 2011).

The meanings attributed to loss may or may not facilitate the grieving process (Mazorra, 2009) and thus it is necessary to find a way in which the family can interact and express themselves, that is accessible to all, especially for children. Suppressing feelings of loss can be even more damaging to both the physical and psychic health of the bereaved (Anton \& Favero, 2011).

As shown in this study, the children's needs were poorly met by the environment, which intensified the damage in their confidence and capacity to deal with the loss of loved ones. A remarkable aspect of their emotional development is the loss of creativity, that is, the possibility of feeling real and confident in showing their feelings without losing or damaging the object. Impairment in creative capacity increases the difficulty in mourning the loss of the sibling, which also results in the stagnation of emotional development (they cannot continue to be themselves). Dealing creatively with mourning means being able to demonstrate their fears, frustrations, and growth possibilities without fear of carrying on with life despite their sibling's death.

\section{Conclusion}

A family that loses a child undergoes many complex changes in their routine. The bereaved brothers must deal with losing not only the deceased sibling but also the parents who may no longer be able to offer them what they need. The children in this study showed evidence that they cannot receive the necessary bolding from the environment and have their needs met satisfactorily since parents have not yet been able to work out their own mourning. In this way, relationship with the shared environment is also impaired, because low self-esteem and insecurity prevail over the impossibility of symbolizing and acting spontaneously.

This difficulty in expressing their true self and making use of creativity intensifies their dependence on parental figures, further damaging their acquisition of autonomy. Children fear being abandoned by their families and, realizing their parents' attempts to avoid the subject of their other children's death, feel that they too can be abandoned. Leonardo feels as if his mother did not care enough for mourning her daughter (and consequently did not care for him). Rodrigo was distressed by the imminent sensation of loss (death cannot be presented to the family at any time). And Isabela realized the fragility of maternal figure in performing 
her role and supporting her development (she cannot rely on the care her mother offers).

In an attempt to get the family to mourn, children take it upon themselves, as if they are able to present loss to their parents and help them cope with it, but they are still deprived of the creative capacity to elaborate their own mourning because they need shelter and safety in order to do it. Consequently, they end up experiencing losses (in the shape of learning difficulty) and symptoms that require the care and protection of the family environment, even if it seems too fragile to them. Therefore, children clearly cannot cope with the loss of their siblings alone; they need safety and help from their parents, which in turn also denote damages in the necessary creativity to elaborate the loss and continuity of becoming.

It is worth emphasizing that this study brought only the participation of children who sought psychological care (with specific complaints). In addition, it is of paramount importance to understand the psychodynamic functioning of parents and the experience of parenting when there was the loss of a child. Feelings derived from loss, in both parents and children, need to be worked out so that these parents can regain their own creative capacity and thereby assist their children in acquiring the necessary creativity to deal with the loss of the sibling and difficult moments that arise in the course of their lives. Only then, it will be possible for them to live creatively, that is, to feel real, with one's own unique existence.

\section{References}

Aberastury, A. (1982). Conflitos na elaboração do luto. In A. Aberastuy, Psicanálise da Criança - Teoria e Técnica (A. L. L. Campos, trad. pp.180-210). Porto Alegre, Artes Médicas Aberastury.

Aberastury, A. (1984). A percepção da morte na criança. In A. Aberastury, \& Colaboradores, A percepção da morte nas criancas e outros escritos (M. N, Folberg, trad., pp.128-139). Porto Alegre, Artes Médicas.

Abram, J. (2000). A linguagem de Winnicott. Rio de Janeiro: Revinter. (Trabalho original publicado em 1996)

Anton, M. C., \& Favero, E. (2011). Morte repentina de genitores e luto infantil: uma revisão da literatura em periódicos científicos brasileiros. Interação em Psicologia, 15(1), 101-110. doi: http://dx.doi. org/10.5380/psi.v15i1.16992
Barone, K. C. (2004). Realidade e luto: um estudo da transicionalidade. São Paulo: Casa do Psicólogo.

Bromberg, M. H. P. F. (1994). A psicoterapia em situações de perdas e luto. Campinas: Editorial Psy.

Bowlby, J. (1998). Apego e perda. In J. Bowlby, Separação: Angústia e raiva (L. Hegenberg, O. Motta \& M. Hegenberg, trads., v.2) São Paulo: Martins Fontes. (Trabalho original publicado em 1973)

Buck, J. N. (2003). HTP Manual e Guia de Interpretaşão (R. C. Tardivo, trad.). São Paulo: Vetor. (Trabalho original publicado em 1964)

Cunha, J. A., \& Nunes, M. A. T. (1993). Teste das Fábulas: Forma Verbal e Pictórica. São Paulo: Centro editor de testes e pesquisas em psicologia.

Figle, N., Fontes, A., Moraes, \& Paya, R. (2004). Filhos de dependentes químicos com fatores de risco bio-psicossociais: necessitam de um olhar especial? Rev. Psiq. Clin., 31(2), 53-62. doi: http://dx.doi. org/10.1590/S0101-60832004000200001

Gerhardt, C. A., Fairclough, D. L., Grossenbacher, J. C., Barrera, M., Gilmer, M. J., Foster, T. L., Compas, B. E., Davies, B., Hogan, N. S., \& Vannatta, K. (2012). Peer relationships of bereaved siblings and comparison classmates after a child's death from cancer. Journal of Pediatric Psychology, 37(2), 209-219. doi: 10.1093/jpepsy/jsr082

Goldsmid, R., Féres-Carneiro, T. (2011). Relação fraterna: constituição do sujeito e formação do laço social. Psicologia USP on line, 22(4), 771-788. doi: http:// dx.doi.org/10.1590/S0103-65642011005000031

Graham, A. (2004). Life is like the seasons: responding to change, loss, and grief through a peer-based education program. Childhood Education, 80(6), 317325. doi: 10.1080/00094056.2004.10521278

Green, A. A. (1988). Narcisismo de vida-Narcisismo de morte. São Paulo: Escuta.

Green, E. J., \& Connolly, M. E. (2009). Jungian family sandplay with bereaved children: implications for Play Therapists. International Journal of Play Therapy, 18(2), 84-89. doi: http://dx.doi.org/10.1037/ a0014435

Heath, M. A., \& Cole, B. V. (2011). Strengthening classroom emotional support for children following a family member's death. School Psychology International, 33(3), 243-262. doi: 10.1177/0143034311415800 
Howarth, R. A. (2011). Promoting the Adjustment of Parentally Bereaved Children. Journal of Mental Health Counseling, 33(1), 21-32. doi: http://dx.doi. org/10.17744/mehc.33.1.a2m06x0835352741

Ireland, V. E. (2011). A dor do luto e seu acolhimento psicanalítico. Estudos de Psicanálise, 35(1), 151-166. Endereço eletrônico: http://pepsic. bvsalud.org/scielo.php? script $=$ sci_arttext\&pid $=$ S010034372011000200016

Kovács, M. J. (1992). Morte e desenvolvimento bumano. São Paulo: Casa do Psicólogo.

Kübler-Ross, E. (2005). Sobre a morte e o morrer (P. Menezes, trad.). São Paulo: Martins Fontes. (Trabalho original publicado em 1981)

Librach, S. L., \& O’Brien, H. (2011). Supporting children's grief within an adult and pediatric palliative care program. Journal of Supportive Oncology, 9(4), 136-140. doi: 10.1016/j.suponc.2011.04.003

Lima, V. R., \& Kovács, M. J. (2011). Morte na família: um estudo exploratório acerca da comunicação à criança. Psicologia: Ciência e Profissão, 31(2), 390-405. doi: http://dx.doi.org/10.1590/ S1414-98932011000200014

Mazorra, L. (2009). A construção de significados atribuidos à morte de um ente querido e o processo de luto. Tese de Doutorado, Pontifica Universidade Católica de São Paulo, São Paulo.

Pereira, C. R. R. (2011). Rivalidade fraterna na perspectiva dos progenitores: da gestação ao segundo ano de vida do segundo filho. Tese de Doutorado, Instituto de Psicologia da Universidade Federal do Rio Grande do Sul.
Pincus, L. (1989). A familia e a morte: como enfrentar o luto (F. Murad, trad.). Rio de Janeiro: Editora Paz e Terra.

Torres W. C. (1999). A criança diante da morte: desafios. São Paulo: Casa do Psicólogo.

Trinca W. (1984). Diagnóstico Psicológico. São Paulo: EPU.

Zimerman, D. (1993). Fundamentos básicos das grupoterapias. Porto Alegre: Artmed.

Winnicott, D. W. (1975). A criatividade e suas origens. In D. W. Winnicott, O brincar e a realidade (J. O. A. Abreu \& V. Nobre, trads., pp. 95-120). Rio de Janeiro: Imago. (Trabalho original publicado em 1971)

Winnicott, D. W. (1997). Uma abordagem clínica aos problemas familiares: a família. In D. W. Winnicott, Pensando sobre crianças (M. A. V. Veronese, trad., pp. 70-72). Porto Alegre: Artes Médicas. (Trabalho original publicado em 1959)

Winnicott, D. W. (2008). Distorção do ego em termos de falso e verdadeiro "self". In D. W. Winnicott, $O$ ambiente e os processos de maturação (I. C. S. Ortiz, trad., pp. 128-139). Porto Alegre: Artes Médicas. (Trabalho original publicado em 1960)

Winnicott, D. W (2012). Agressão e suas raízes. In D. W. Winnicott, Privação e delinquência (A. Cabral, trad., pp. 93-110). São Paulo: Martins Fontes. (Trabalho original publicado em 1939)

Winnicott, D. W (2012). A Psicologia da separação. In D. W. Winnicott, Privação e delinquência (A. Cabral, trad., pp. 149-152). São Paulo: Martins Fontes. (Trabalho original publicado em 1958)

Recebido em: 13-06-2016 Reformulado em: 16-11-2016; 03-02-2017 Aprovado em: 03-03-2017 
Sobre as autoras:

Marcela Lança de Andrade, Psychologist and PhD candidate, Department of Psychology of the Faculty of Philosophy, Sciences and Literature of Ribeirão Preto of the Universidade de São Paulo; Ribeirão Preto/SP.

E-mail: marcela.andrade@usp.br

Fernanda Kimie Tavares Mishima-Gomes, PhD and Psychologist, Department of Psychology of the Faculty of Philosophy, Sciences and Literature of Ribeirão Preto of the Universidade de São Paulo; Ribeirão Preto/SP.

E-mail: ferkimie@yahoo.com.br

Valéria Barbieri, Professor PhD, Department of Psychology of the Faculty of Philosophy, Sciences and Literature of Ribeirão Preto of the Universidade de São Paulo; Ribeirão Preto/SP.

E-mail: valeriab@ffclrp.usp.br

Contato com as autoras:

Av. Bandeirantes, 3900

Vila Monte Alegre, Ribeirão Preto-SP, Brasil

CEP: 14040-900 